\title{
The Younger Site (41MR6), Marion County, Texas
}

Timothy K. Perttula

Heritage Research Center, Stephen F. Austin State University

Mark Walters

Heritage Research Center, Stephen F. Austin State University

Bo Nelson

Heritage Research Center, Stephen F. Austin State University

Follow this and additional works at: https://scholarworks.sfasu.edu/ita

Part of the American Material Culture Commons, Archaeological Anthropology Commons, Environmental Studies Commons, Other American Studies Commons, Other Arts and Humanities Commons, Other History of Art, Architecture, and Archaeology Commons, and the United States History Commons

Tell us how this article helped you.

This Article is brought to you for free and open access by the Center for Regional Heritage Research at SFA ScholarWorks. It has been accepted for inclusion in Index of Texas Archaeology: Open Access Gray Literature from the Lone Star State by an authorized editor of SFA ScholarWorks. For more information, please contact cdsscholarworks@sfasu.edu. 


\section{The Younger Site (41MR6), Marion County, Texas}

Creative Commons License

(c) (i) (8)

This work is licensed under a Creative Commons Attribution-NonCommercial 4.0 International License 


\title{
The Younger Site (41MR6), Marion County, Texas
}

\author{
Timothy K. Perttula, Mark Walters, and Bo Nelson
}

The Younger site (41MR6) is located on a lower toe slope (250 ft. amsl) and alluvial terrace in the Arms Creek or Patton Creek valley at Lake O' the Pines. Arms Creek is an eastward-flowing tributary to Big Cypress Creek. At normal pool levels the Younger site is now under the waters of I ake O' the Pines.

When the site was first recorded by E. O. Miller of the National Park Service in 1951 (Miller et al. 1951), it was named the D. M. Collom site. The site was estimated to cover 6-8 acres, and was marked by several areas of bare ground where Caddo pottery sherds were collected $(n=150)$, primarily plain sherds $(n=115)$ and brushed/brushed-punctated sherds ( $n=33$ ). Thurmond (1990:69) considers the site to be a large Titus phase settlement based on the identification of Ripley/Taylor Engraved, Glassell Engraved, Maydelle Incised, Bullard Brushed, and Pease Brushed-Incised sherds in the collection as well as a single Maud arrow point.

In April 1964, Buddy Calvin Jones excavated four burials in a prehistoric Caddo cemetery at what was now known as the A. V. Younger site (Figure 1). The burials were about $30 \mathrm{~m}$ north of a spring-fed creek, in a row situated near the edge of a small alluvial terrace (Figure 2). The burials each contained a single individual laid out in an extended, supine position with associated funerary offerings, primarily ceramic vessels. We documented a number of the ceramic vessels, as descrihed below, but eight of the vessels recovered by Jones are now missing from the collection.

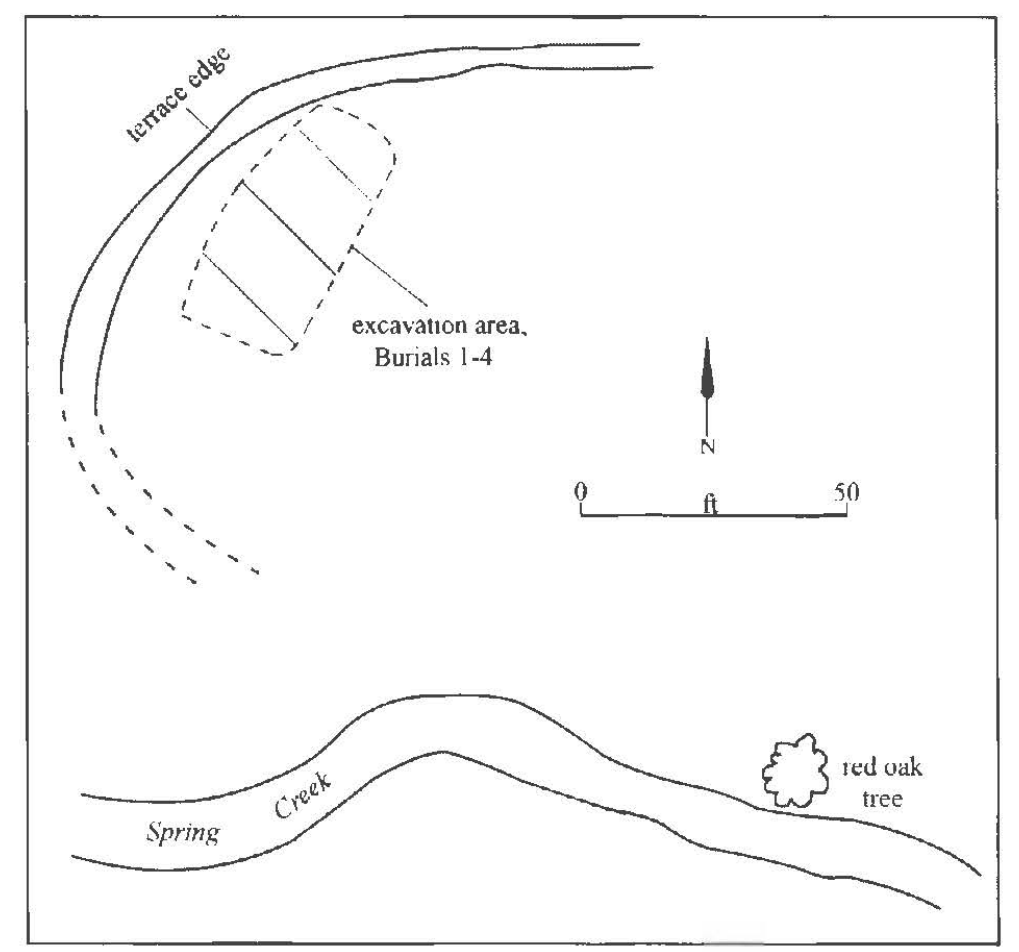

Figure 1. Buddy Calvin Jones' map of the A.V. Younger site cemetery area. 


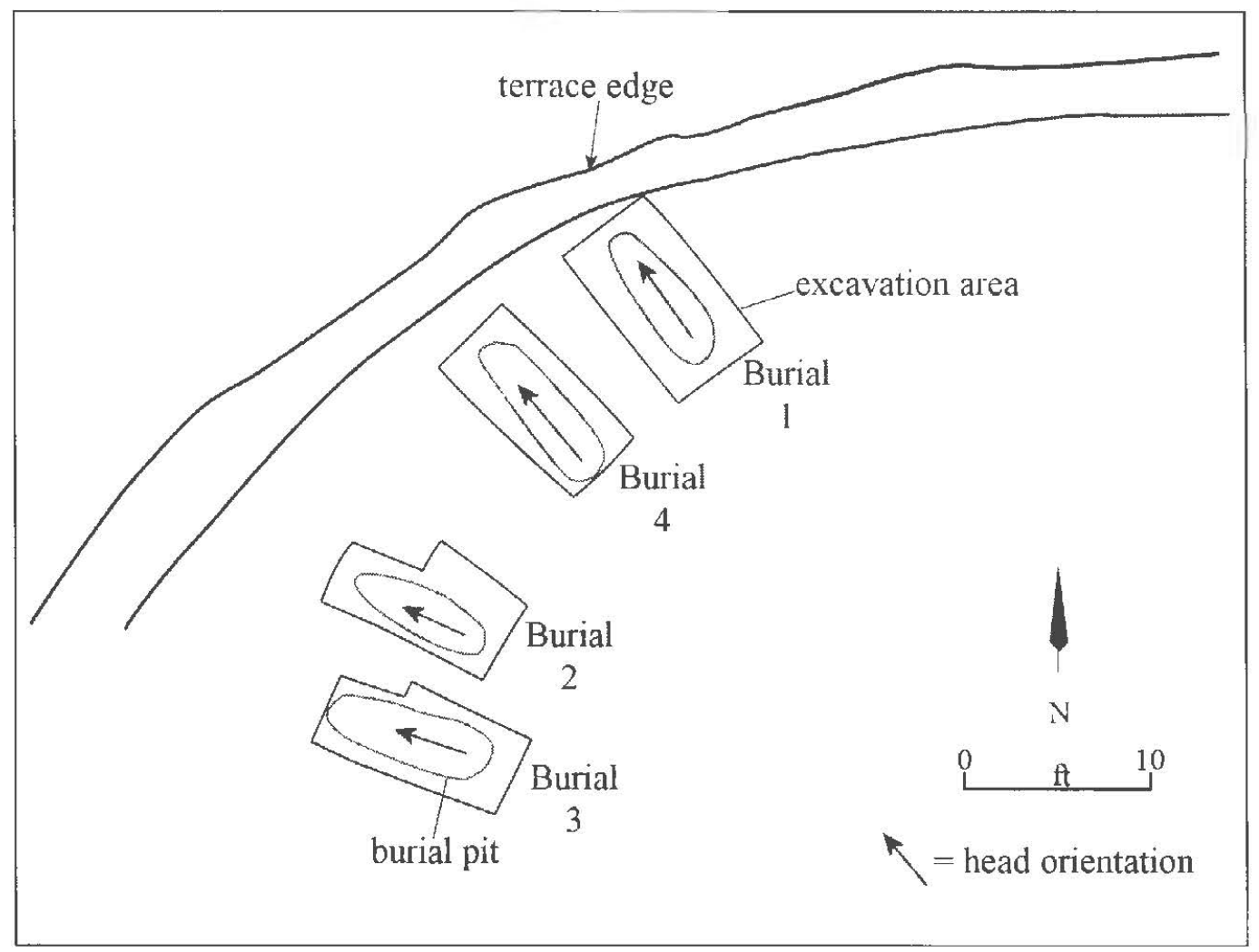

Figure 2. Plan of Burials 1-4 on the alluvial terrace.

\section{Burial 1}

Burial 1 had been placed in a grave that was $2.38 \mathrm{~m}$ in length, $0.86 \mathrm{~m}$ in width, and the floor of the grave lay at $0.74 \mathrm{~m}$ below the surface; based on the size of the burial pit, the deceased was an adult. The fill was comprised of midden sediments, ashes, and sherds from midden deposits that must occur on the site. Only small fragments of the skull and leg bones were preserved in the burial (Figure 3). The head of the deceased was oriented to the northwest.

Funerary offerings included a single broken Bonham arrow point placed near the lower right leg and four vessels arranged along the right side of the body from the shoulder to the upper right leg (see Figure 3 ). Vessel 1 in this burial was by the right shoulder. The other vessels - now missing from the collectioninclude a small incised-punctated carinated bowl, a Pease Brushed-jar, and a medium-sized plain bowl

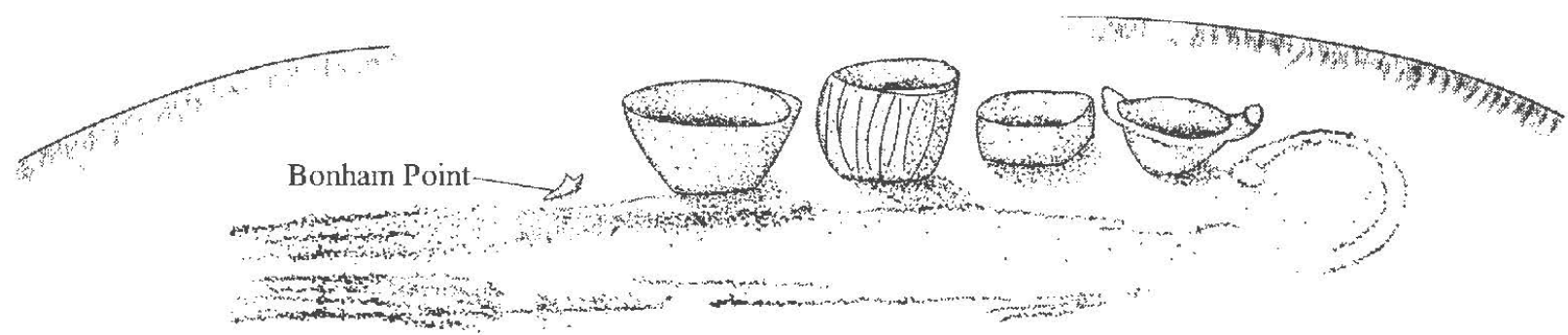

Figure 3. Burial 1 map drawn by Buddy Calvin Jones. 
VESSEL NO.: Burial 1, Vessel 1, 2003.08.214

NON-PLASTICS AND PASTE: grog

VESSEL FORM: Bowl with two opposed rim peaks (Figure 4).

RIM AND LIP FORM: everted rim and a rounded lip

CORE COLOR: $\mathrm{F}$ (fired in a reducing environment and cooled in the open air)

INTERIOR SURFACE COLOR: reddish-brown; fire clouds on the rim

EXTERIOR SURFACE COLOR: reddish-brown; fire clouds on the rim and body

WALL THICKNESS (RIM, BODY, AND BASE IN MM): rim, $6.7 \mathrm{~mm}$

INTERIOR SURFACE TREATMENT: none

EXTERIOR SURFACE TREATMENT: smoothed

HEIGHT (IN CM): $6.8 ; 9.5 \mathrm{~cm}$ at the rim peaks

ORIFICE DIAMETER (IN CM): 12.5

DIAMETER AT BOTTOM OF RIM OR NECK (IN CM): N/A

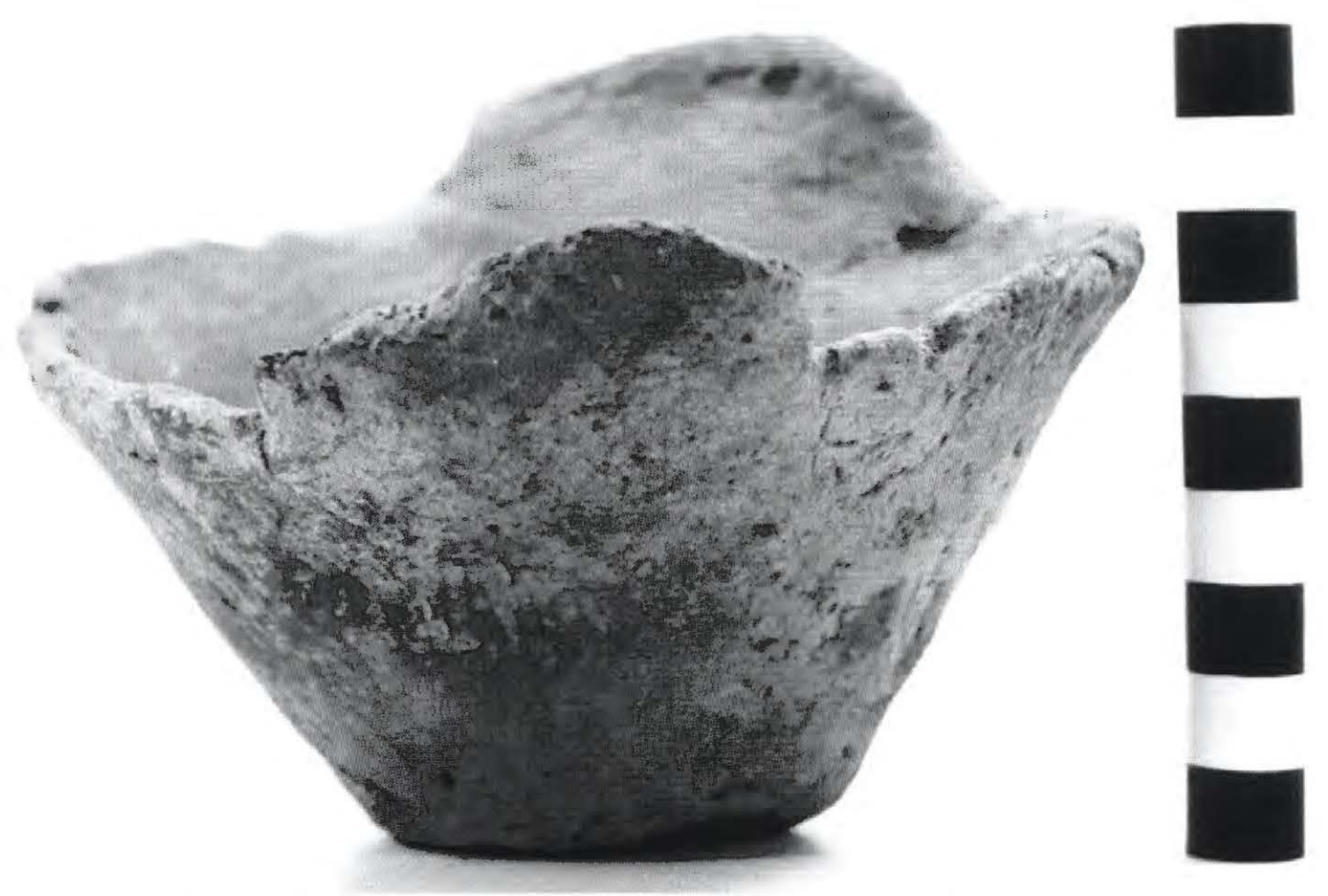

Figure 4. Plain bowl with rim peaks, Burial 1, Vessel 1 at the A. V. Younger site. 
4 Journal of Northeast Texas Archaeology 38 (2012)

BASE DIAMETER (IN CM) AND SHAPE OF BASE: 5.5 ; circular and flat

ESTIMATED VOLUME (IN LITERS): 0.34

DECORATION (INCLUDING MOTIF AND ELEMENTS WHEN APPARENT): Plain

PIGMENT USE AND LOCATION ON VESSEL: none

TYPE AND VARIETY [IF KNOWN]: Unidentified plain ware

\section{Burial 2}

Burial 2 was that of an adult placed in a grave pit that was $1.85 \mathrm{~m}$ in length, $0.69 \mathrm{~m}$ in width (Figure 5 ), and the floor of the burial pit was identified at $0.71 \mathrm{~m}$ below surface. The burial fill was comprised of darkly-stained midden deposits with pottery sherds, charcoal, and lithic debris. Skeletal remains were poorly preserved, but suggest that the deceased was approximately $1.57 \mathrm{~m}$ in length, and was likely an adult female; the teeth were described by Jones as well-worn. The pit itself and the individual placed in an extended supine position in it, were oriented west-northwest, with the head facing in that direction.

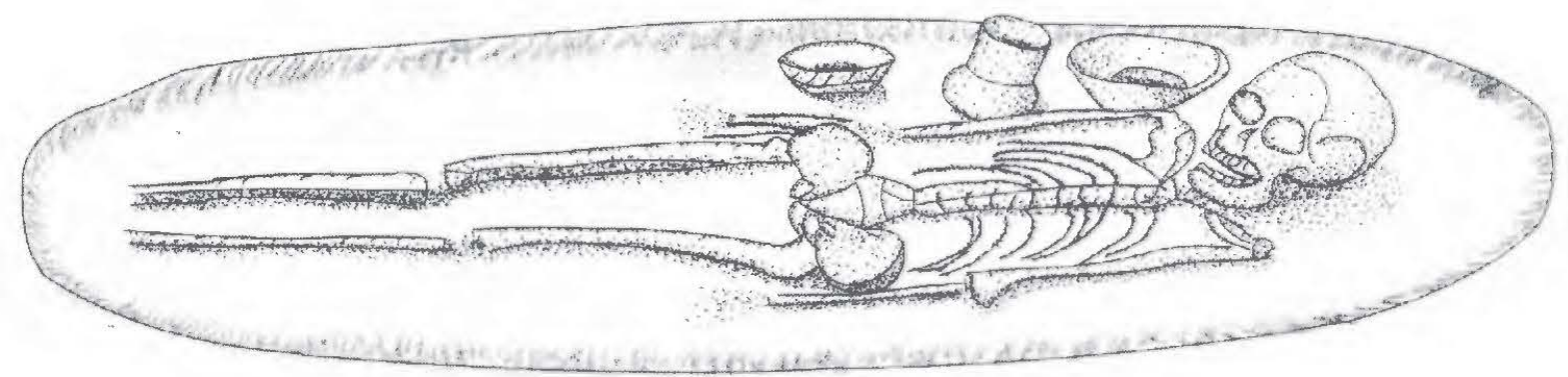

Figure 5. Plan map of Burial 2 drawn by Buddy Calvin Jones.

Funerary offerings placed with the deceased consisted of three ceramic vessels. They were placed on the right side of the body, from the shoulder to the hip (see Figure 5). Vessel 5, a plain bowl, was placed by the right shoulder; Vessel 6 , an incised-punctated jar with suspension holes, was by the right arm; and Vessel 7, an incised-punctated carinated bowl, was by the right hip.

VESSEL NO.: Burial 2, Vessel 5; 2003.08.225

NON-PLASTICS AND PASTE: grog and bone

VESSEL FORM: Bowl (Figure 6)

RIM AND LIP FORM: direct rim and a rounded lip

CORE COLOR: $F$ (fired in a reducing environment and cooled in the open air)

INTERIOR SURFACE COLOR: reddish-brown; fire clouding on the base 


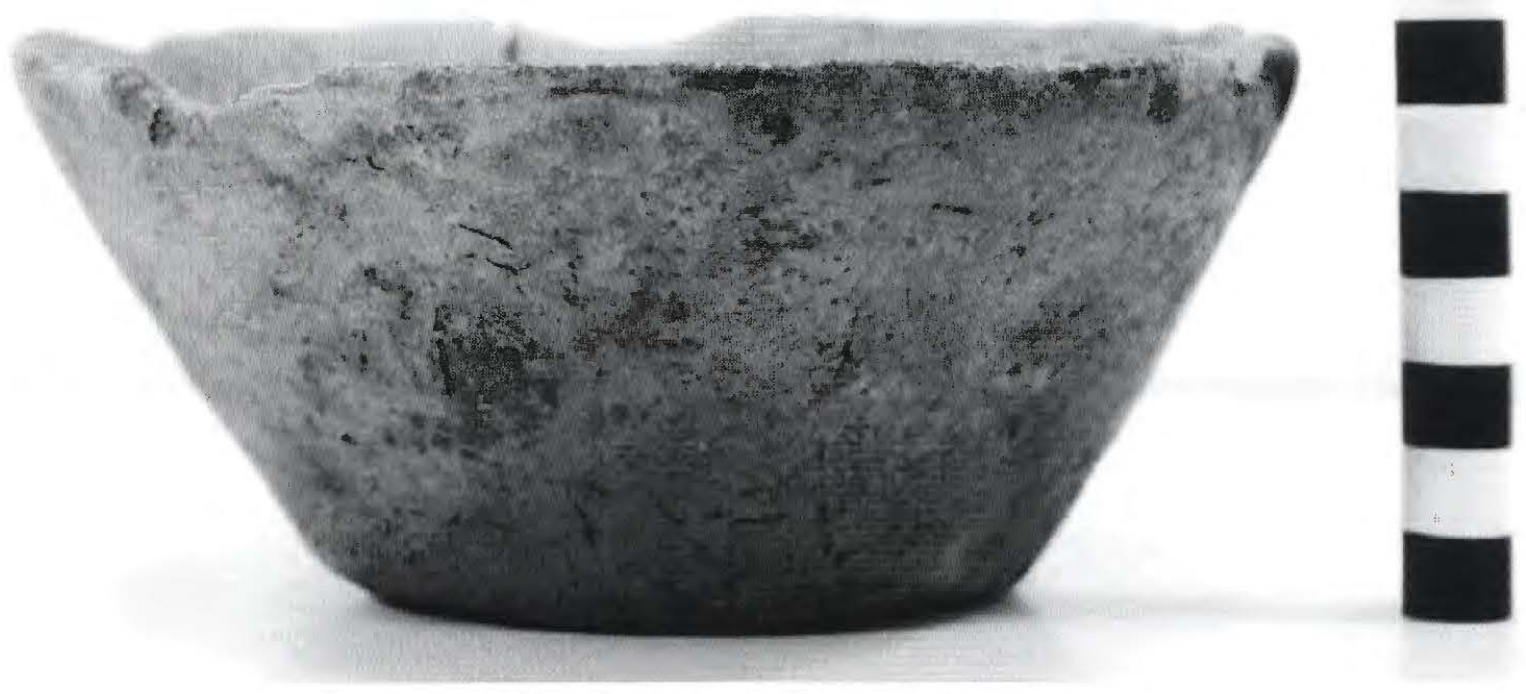

Figure 6. Plain bowl, Burial 2, Vessel 5, at the A. V. Younger site.

EXTERIOR SURFACE COLOR: dark yellowish-brown; fire clouds on the body and base

WALL THICKNESS (RIM, BODY,AND BASE IN MM): rim, $6.2 \mathrm{~mm}$

INTERIOR SURFACE TREATMENT: none

EXTERIOR SURFACE TREATMENT: smoothed

HEIGHT (IN CM): 7.0

ORIFICE DIAMETER (IN CM): 15.7

DIAMETER AT BOTTOM OF RIM OR NECK (IN CM): N/A

BASE DIAMETER (IN CM) AND SHAPE OF BASE: 8.5 ; circular and flat base

ESTIMATED VOLUME (IN LITERS): 0.44

DECORATION (INCLUDING MOTIF AND ELEMENTS WHEN APPARENT): Plain

PIGMENT USE AND LOCATION ON VESSEL: none

TYPE AND VARIETY [IF KNOWN]: Unidentified plain ware 
6 Journal of Northeast Texas Archaeology 38 (2012)

VESSEL NO:: Burial 2, Vessel 6; 2003.08.213

NON-PLASTICS AND PASTE: grog and hematite

VESSEL FORM: Jar with two opposed suspension holes (Figure 7) and a tall rim

RIM AND LIP FORM: Everted rim and a flat lip

CORE COLOR: $\mathrm{G}$ (fired in a reducing environment and cooled in the open air)

INTERIOR SURFACE COLOR: dark grayish-brown; organic residue on the rim

EXTERIOR SURFACE COLOR: reddish-brown; organic residue on the rim and body

WALL THICKNESS (RIM, BODY, AND BASE IN MM): rim, $6.6 \mathrm{~mm}$

INTERIOR SURFACE TREATMENT; smoothed

EXTERIOR SURFACE TREATMENT: nOne

HEIGHT (IN CM): 11.5

ORIFICE DIAMETER (IN CM): 9.6

DIAMETER AT BOTTOM OF RIM OR NECK (IN CM): 8.5

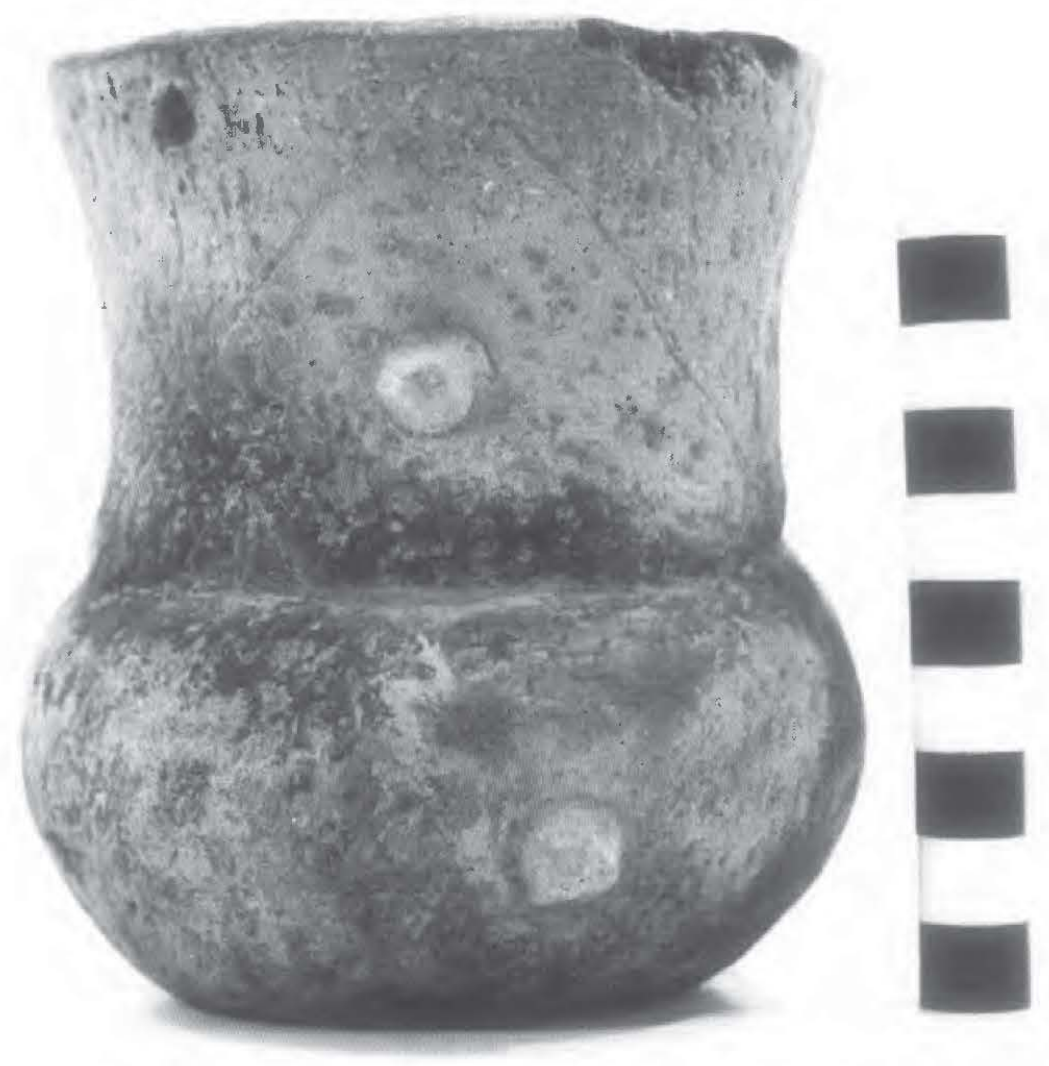

Figure 7. Incised-punctated and appliqued jar, Burial 2, Vessel 6, at the A.V. Younger site. 
BASE DIAMETER (IN CM) AND SHAPE OF BASE: 7.2; circular and flat

ESTIMATED VOLUME (IN LITERS): 0.66

DECORATION (INCLUDING MOTIF AND ELEMENTS WHEN APPARENT): The rim and body have incised-punctated motifs (Figure 7). The rim has opposed incised lines, repeated five times, filled with tool punctations; there are also two large opposed appliqued nodes on the rim. The vessel body has four sets of stacked alternating incised triangles. On the lower set, the incised triangles are filled with tool punctations; the upper set consists solely of incised triangles with a large appliqued node set near the apex of the triangles (Figure 7).

PIGMENT USE AND LOCATION ON VESSEL: none

TYPE AND VARIETY [IF KNOWN]: Unidentified utility ware

VESSEL NO.: Burial 2, Vessel 7, 2003.08.222

NON-PLASTICS AND PASTE: grog

VESSEL FORM: Carinated bowl

RIM AND LIP FORM: Everted rim and a rounded lip

CORE COLOR: $\mathrm{G}$ (fired in a reducing environment and cooled in the open air)

INTERIOR SURFACE COLOR: dark grayish-brown; fire clouds on the body

EXTERIOR SURFACE COLOR: yellowish-brown; organic residue on the rim-body juncture

WALL THICKNESS (RIM, BODY, AND BASE IN MM): rim, $5.0 \mathrm{~mm}$

INTERIOR SURFACE TREATMENT: smoothed on the rim

EXTERIOR SURFACE TREATMENT: none

HEIGHT (IN CM): 3.8

ORIFICE DIAMETER (IN CM): 11.0

DIAMETER AT BOTTOM OF RIM OR NECK (IN CM): 9.0

BASE DIAMETER (IN CM) AND SHAPE OF BASE: 6.2; flat and circular

ESTIMATED VOLUME (IN LITERS): 0.25

DECORATION (INCLUDING MOTIF AND ELEMENTS WHEN APPARENT): The rim panel has 11 diagonal incised scrolls with a central circular to rectangular incised element. Fach scroll is associated with triangular areas filled with small circular punctations (Figure 8). There are also two rows of small circular punctations under the lip and a third row at the vessel carination. 

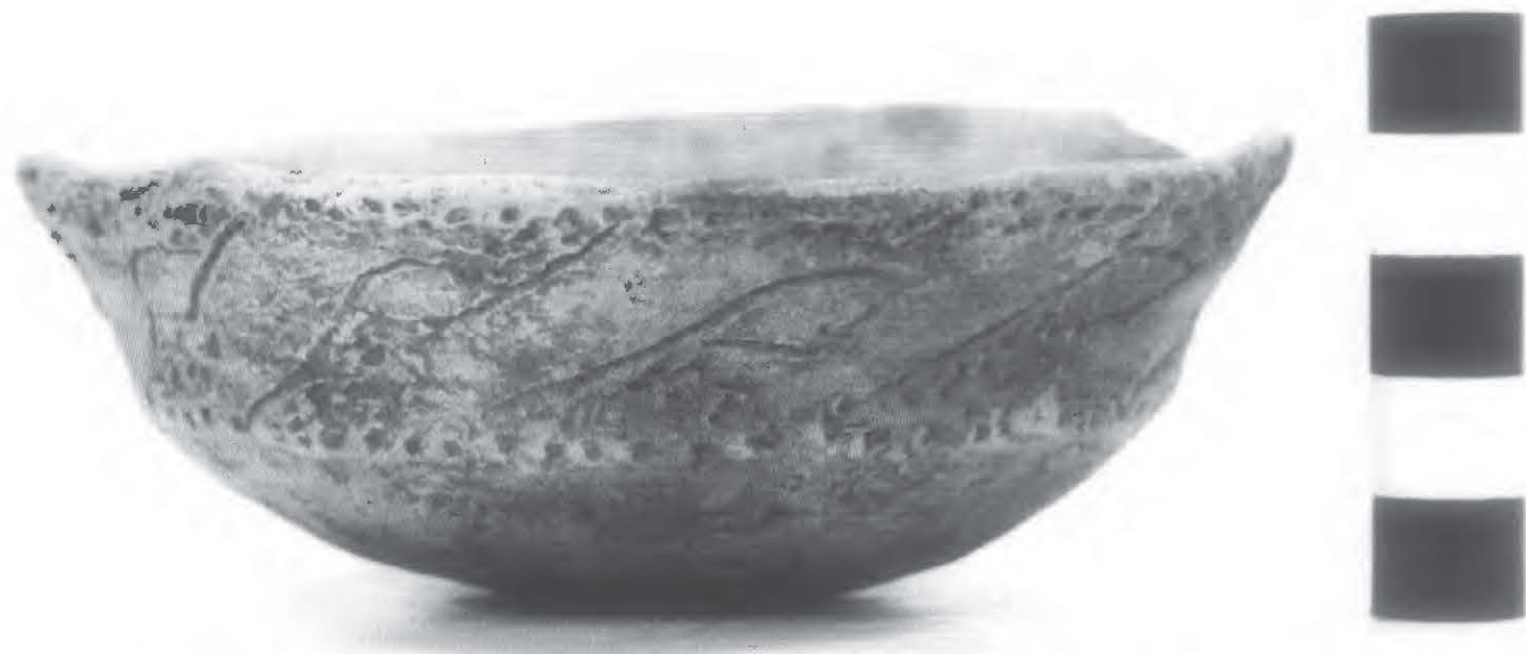

Figure 8. Incised-punctated carinated bowl, Burial 2, Vessel 7, at the A. V. Younger site.

\section{PIGMENT USE AND LOCATION ON VESSEL: none}

TYPE AND VARIETY [IF KNOWN]: Unidentified utility ware

\section{Burial 3}

This adult Caddo burial was placed in a $2.39 \mathrm{~m}$ long and $0.76 \mathrm{~m}$ wide grave (Figurc 9). The floor of the grave was at $0.74 \mathrm{~cm}$ bs. The individual was placed in the pit in an extended supine position with the head facing towards the west-northwest. The burial fill was a darkly-stained midden deposit with pottery sherds and wood charcoal. Approximately $30 \mathrm{~cm}$ above the head of the burial was the top of a $30 \mathrm{~cm}$ diameter area of charcoal, burned bone, pottery sherds, and what was identified by Jones as a black chert Pogo point (i.e., large contracting stem dart point or biface; see Suhm and Jelks [1962:Plate 82]). This small feature was placed directly above the skull, and may represent the remains of a ceremony/ritual carried out by the Caddo as part of the interment.

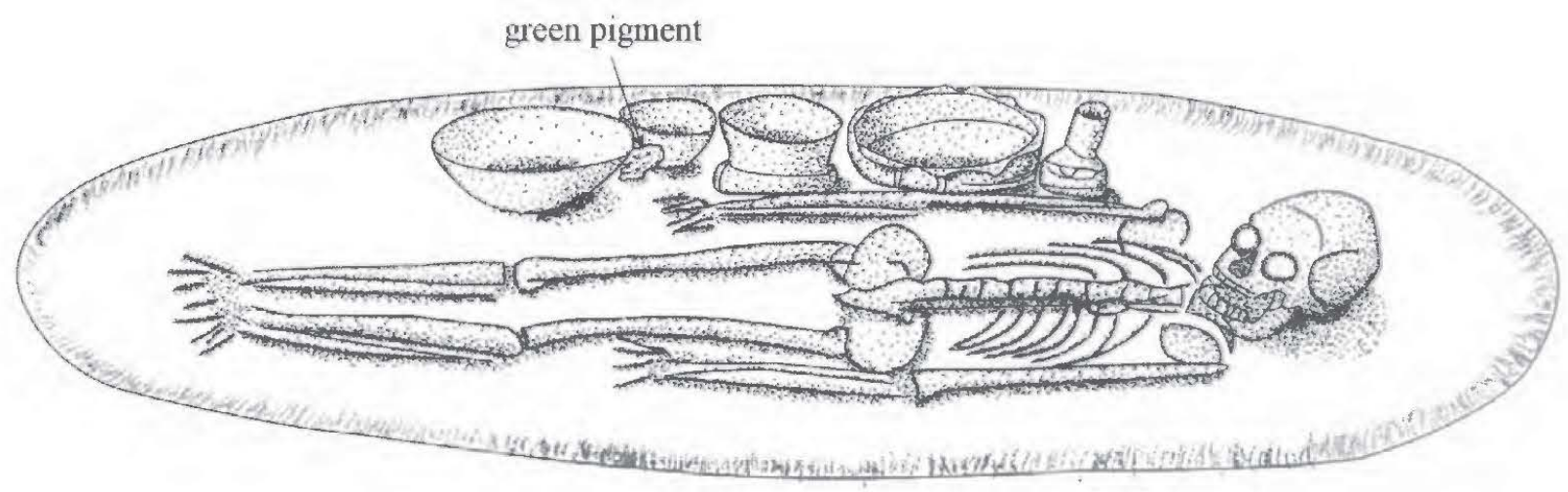

Figure 9. Burial 3 plan map drawn by Buddy Calvin Jones. 
Burial 3 had five vessels and a small mass of green glauconitic clay pigment placed as funerary offerings with the deceased. Only two of the five vessels remain in the collection at the Gregg County Historical Museum. Both are plain bowls (Vessels 11 and 12) that had been placed along the right side of the body by the right leg (see Figure 9); the green pigment lay between these two vessels. The other vessels included a bottle by the right shoulder that had an engraved rattlesnake motif on it (see Walters 2006), a scalloped plain bowl by the right arm, and a plain jar by the lower right arm and hip.

VESSEL NO.: Burial 3, Vessel 11, 2003.08.1056

NON-PLASTICS AND PASTE: grog

VESSEL FORM: Bowl

RIM AND LIP FORM: Direct rim and a rounded lip

CORE COLOR: $\mathrm{F}$ (fired in a reducing environment and cooled in the open air)

INTERIOR SURFACE COLOR: yellowish-brown

EXTERIOR SURFACE COLOR: yellowish-brown

WALL THICKNESS (RIM, BODY, AND BASE IN MM): rim, $7.9 \mathrm{~mm}$

INTERIOR SURFACE TREATMENT: smoothed

EXTERIOR SURFACE TREATMENT: smoothed

HEIGHT (IN CM): 4.5

ORIFICE DIAMETER (IN CM): 10.6

DIAMETER AT BOTTOM OF RIM OR NECK (IN CM): N/A

BASE DIAMETER (IN CM) AND SHAPE OF BASE: 5.0, circular and flat

ESTIMATED VOLUME (IN LITERS): 0.19

DECORATION (INCLUDING MOTIF AND ELEMENTS WHEN APPARENT): Plain (Figure 10)

PIGMENT USE AND LOCATION ON VESSEL: none

TYPE AND VARIETY [IF KNOWN]: Unidentified plain ware 


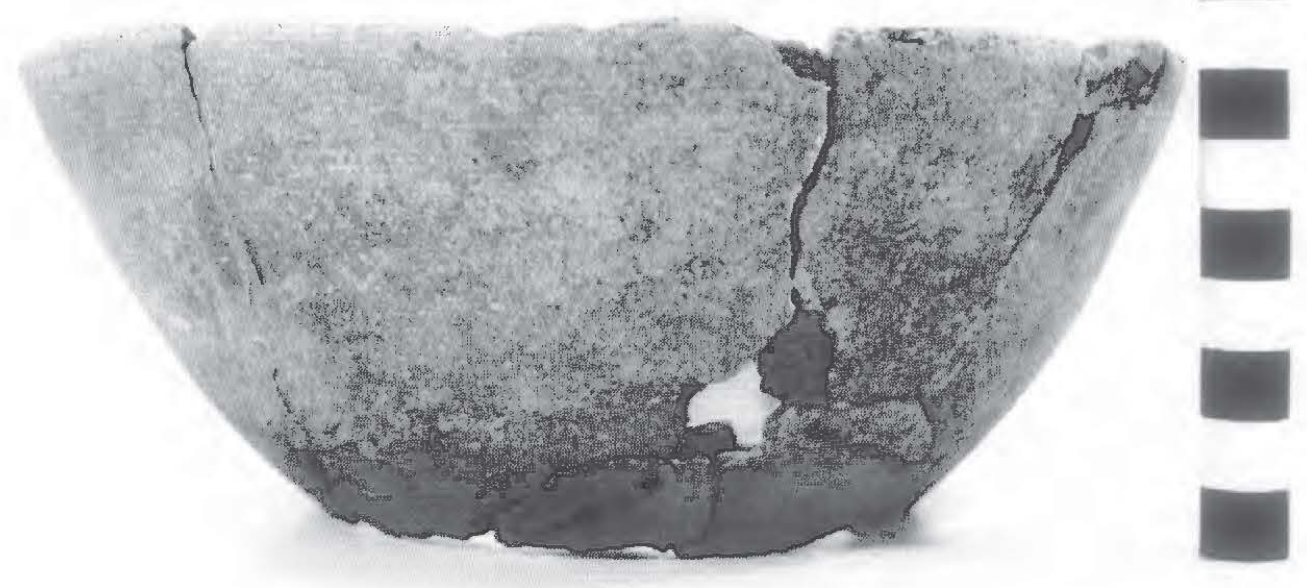

Figure 10. Plain bowl, Burial 3, Vessel 11, from the A. V. Younger site.

VESSEL NO:: Burial 3, Vessel 12; 2003,08.1056

NON-PLASTICS AND PASTE: grog

VESSEL FORM: Bowl

RIM AND LIP FORM: Direct rim and a rounded lip

CORE COLOR: B (fired and cooled in a reducing environment)

INTERIOR SURFACE COLOR: dark grayish-brown

EXTERIOR SURFACE COLOR: dark grayish-brown; fire clouds on the rim and body

WALL THICKNESS (RIM, BODY, AND BASE IN MM): rim, $7.0 \mathrm{~mm}$; body, $6.9 \mathrm{~mm}$; base, $9.2 \mathrm{~mm}$ INTERIOR SURFACE TREATMENT: smoothed

EXTERIOR SURFACE TREATMENT: smoothed

HEIGHT (IN CM): 7.9

ORIFICE DIAMETER (IN CM): 18.3

DIAMETER AT BOTTOM OF RIM OR NECK (IN CM): N/A

BASE DIAMETER (IN CM) AND SHAPE OF BASE: 10.0; circular and flat

ESTIMATED VOLUME (IN LITERS): 0.58

DECORATION (INCLUDING MOTIF AND ELEMENTS WHEN APPARENT): Plain (Figure 11)

PIGMENT USE AND LOCATION ON VESSEL: none

TYPE AND VARIETY [IF KNOWN]: Unidentified plain ware 


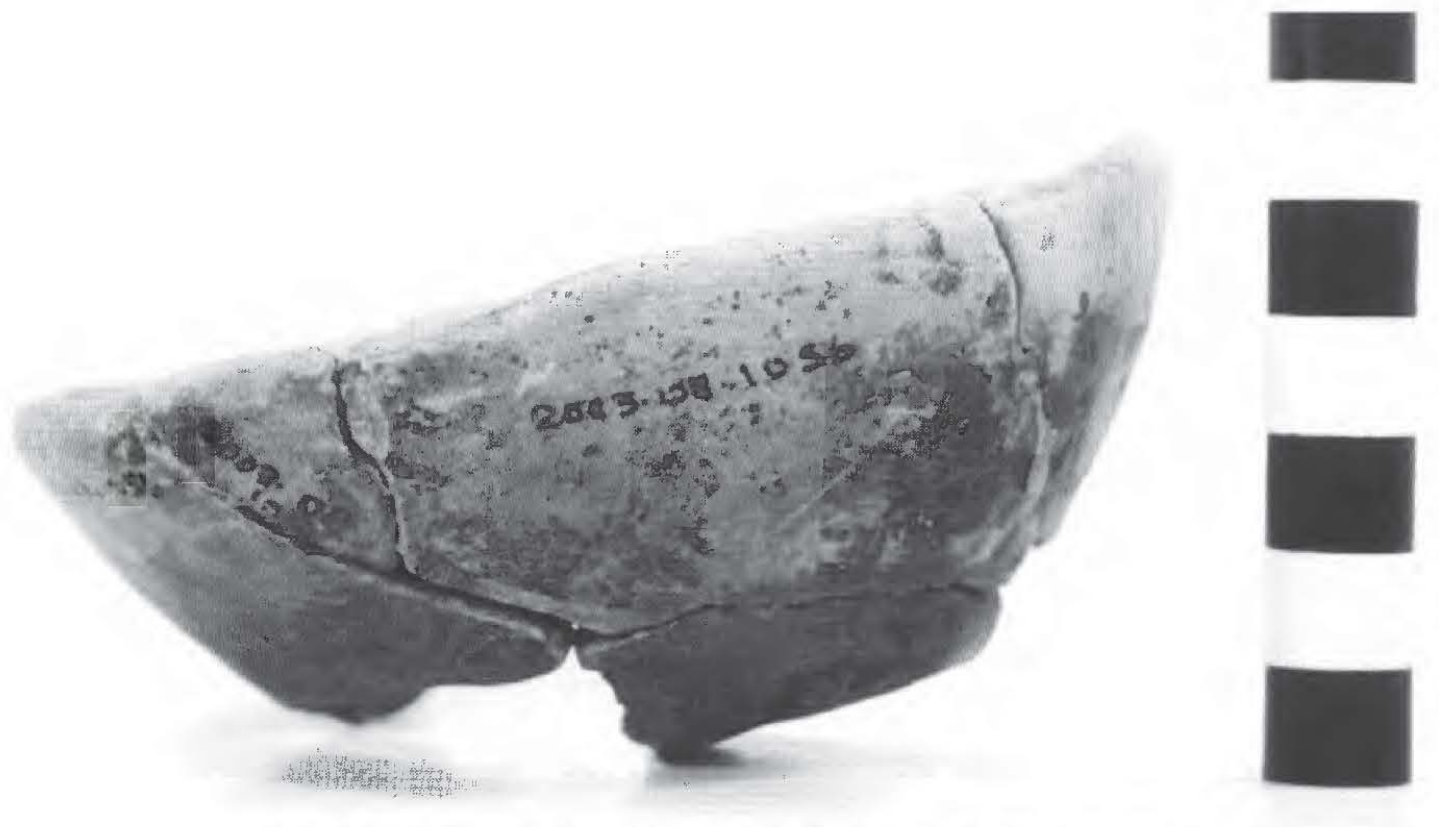

Figure 11. Plain bowl, Burial 3, Vessel 12, at the A. V. Younger site.

\section{Burial 4}

Burial 4 at the A. V. Younger site was that of an adult individual who had been placed in an extended supine position in a $2.13 \mathrm{~m}$ long and $0.89 \mathrm{~m}$ grave; the bottom of the grave lay at $0.71 \mathrm{~m}$ below the surface. The burial pit was oriented northwest-southeast, with the head facing towards the northwest (Figure 12); skeletal remains were very fragmentary. The burial fill was comprised of darkly-stained midden deposit with numerous ceramic sherds and some pieces of lithic debris.

Six ceramic vessels had been placed as funerary offerings in the grave, all along the right side of the body; four of the vessels have been identified in the Gregg County Historical Museum collections. Near the right elbow was an engraved bottle (Vessel 13), followed by an engraved scalloped rimmed bowl by the lower right arm, a plain bowl and a plain carinated bowl (Vessels 15 and 16) were near the right hand, a large engraved carinated bowl was set by the upper right leg, and a Pease Brushed-Incised jar also was set by the upper right leg (see Figure 12).

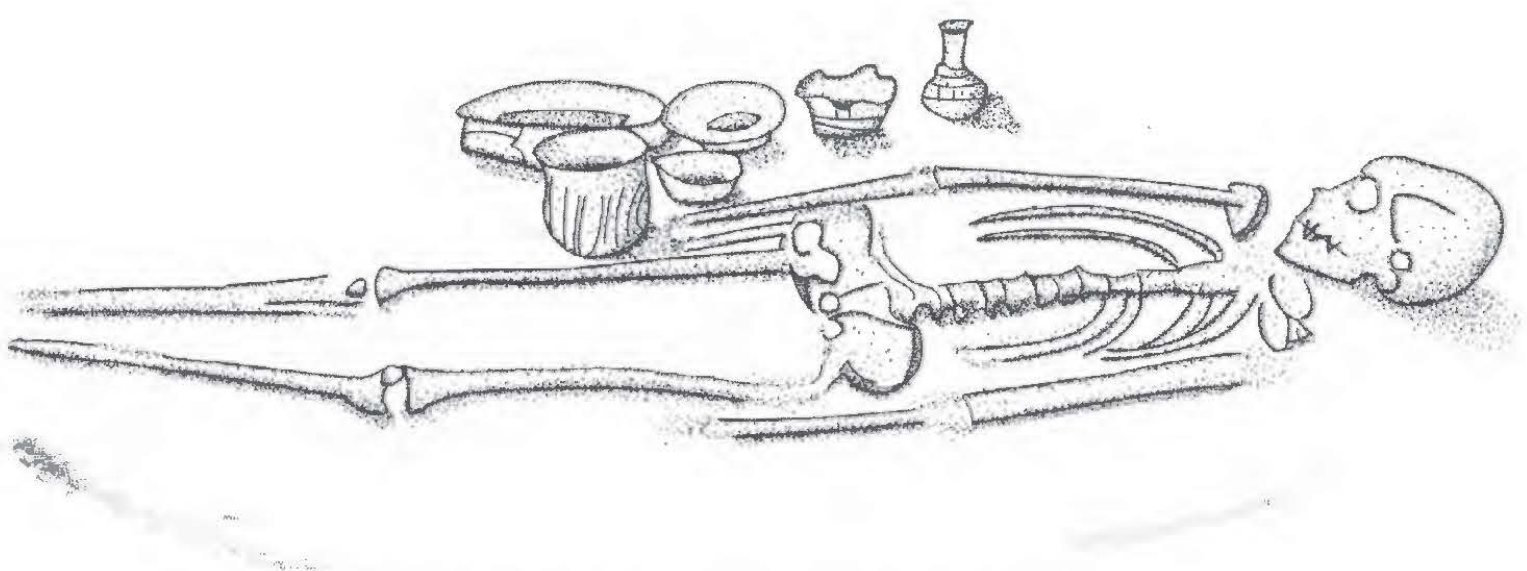

Figure 12. Burial 4 plan map drawn by Buddy Calvin Jones. 
VESSEL NO.: Burial 4, Vessel 13; 2003.08.36

NON-PLASTICS AND PASTE: grog; sandy paste

VESSEL FORM: Bottle with a straight neck

RIM AND LIP FORM: Direct rim and a rounded lip

CORE COLOR: $\mathrm{G}$ (fired in a reducing environment and cooled in the open air)

INTERIOR SURFACE COLOR: dark grayish-brown

EXTERIOR SURFACE COLOR: yellowish-brown; fire clouds on the rim, body, and base

WALL THICKNESS (RIM, BODY, AND BASE IN MM): neck, $6.7 \mathrm{~mm}$

INTERIOR SURFACE TREATMENT: none

EXTERIOR SURFACE TREATMENT: none

HEIGHT (IN CM): 12.0

ORIFICE DIAMETER (IN CM): 3.5

DIAMETER AT BOTTOM OF RIM OR NECK (IN CM): 3.7; maximum body diameter is $7.2 \mathrm{~cm}$

BASE DIAMETER (IN CM) AND SHAPE OF BASE: 4.0; circular and rounded

ESTIMATED VOLUME (IN LITERS): 0.19

DECORATION (INCLUDING MOTIF AND ELEMENTS WHEN APPARENT): The vessel body has a series of horizontal engraved lines below stacks of rectangular engraved zones with closely-spaced vertical engraved lines, curvilinear lines, and large and small excised pendant triangles (Figure 13). One of the upper horizontal engraved lines has excised pendant triangles whose apex points towards the vessel base

PIGMENT USE AND LOCATION ON VESSEL: red pigment in the engraved lines on the vessel body

TYPE AND VARIETY [IF KNOWN]: Unidentified fine ware

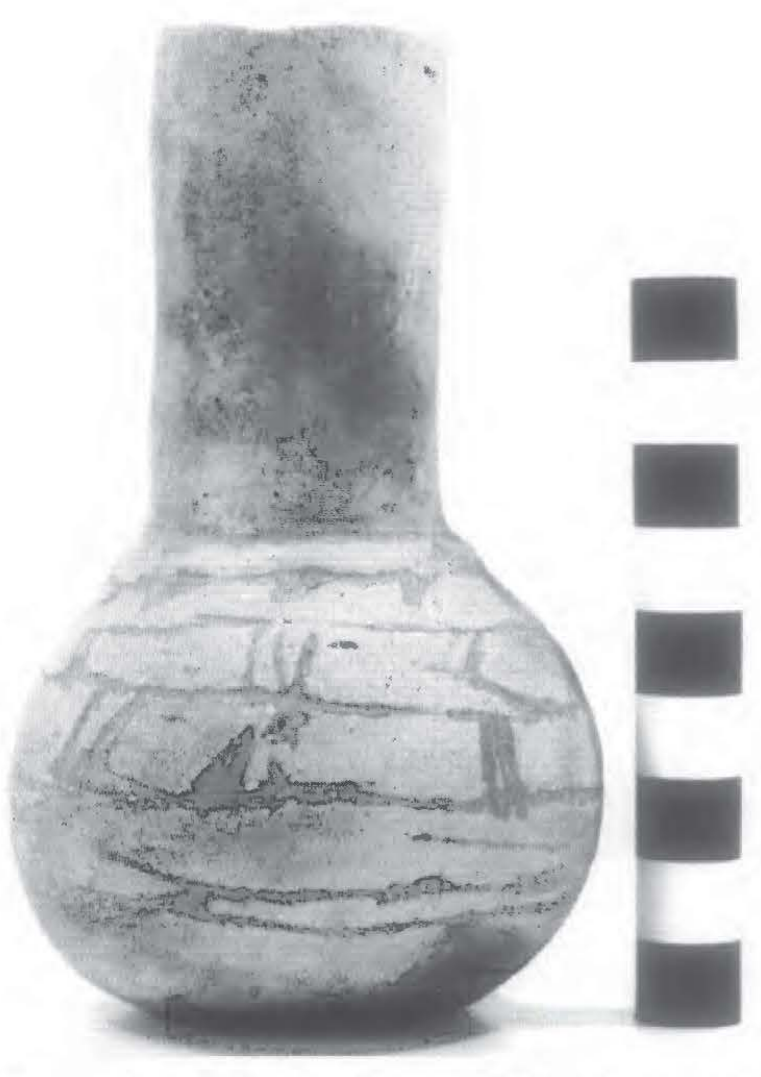

Figure 13. Engraved bottle, Burial 4, Vessel 13, at the A. V. Younger site. 
VESSEL NO:: Burial 4, Vessel 15; 2003.08.217

NON-PLASTICS AND PASTE: grog

VESSEL FORM: Bowl

RIM AND LIP FORM: Direct rim and a rounded base

CORE COLOR: B (fired and cooled in a reducing environment)

INTERIOR SURFACE COLOR: dark grayish-brown

EXTERIOR SURFACE COLOR: dark grayish-brown; fire clouds on the rim, body, and base

WALL THICKNESS (RIM, BODY, AND BASE IN MM): rim, $8.9 \mathrm{~mm}$

INTERIOR SURFACE TREATMENT: none

EXTERIOR SURFACE TREATMENT: none

HEIGHT (IN CM): 5.0

ORIFICE DIAMETER (IN CM): 9.4

DIAMETER AT BOTTOM OF RIM OR NECK (IN CM): N/A

BASE DIAMETER (IN CM) AND SHAPE OF BASE: 6.0; circular and flat

ESTIMATED VOLUME (IN LITERS): 0.19

DECORATION (INCLUDING MOTIF AND ELEMENTS WHEN APPARENT): Plain (Figure 14)

PIGMENT USE AND LOCATION ON VESSEL: none

TYPE AND VARIETY [IF KNOWN]: Unidentified plain ware

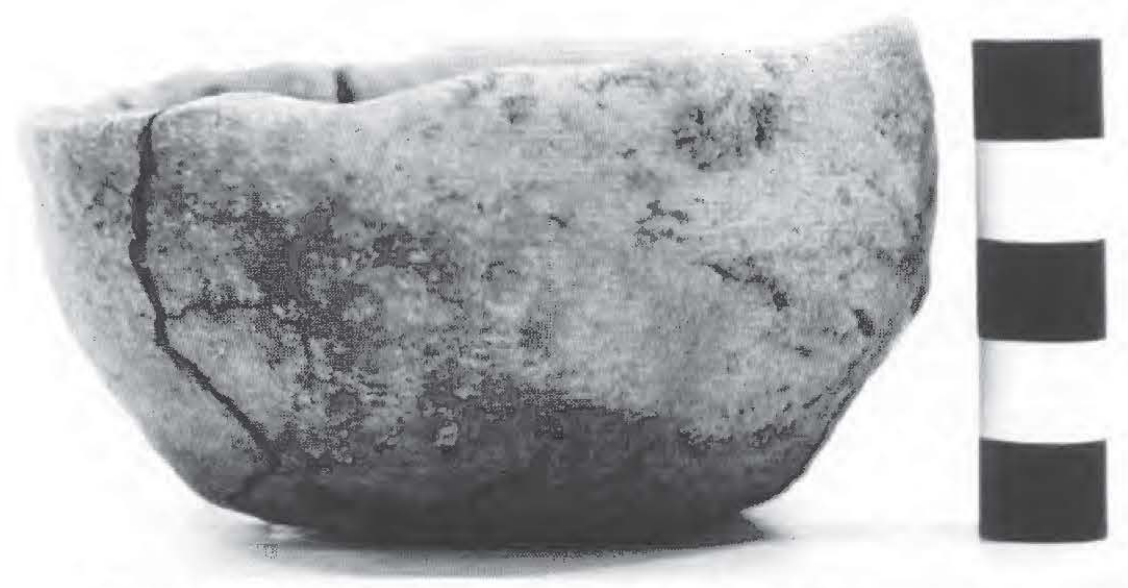

Figure 14. Plain bowl, Burial 4, Vessel 15, at the A. V. Younger site. 
VESSEL NO.: Burial 4, Vessel 16; 2003.08.215

NON-PLASTICS AND PASTE: grog

VESSEL FORM: Carinated bowl

RIM AND LIP FORM: Direct rim and a rounded lip

CORE COLOR: B (fired and cooled in a reducing environment)

INTERIOR SURFACE COLOR: dark grayish-brown

EXTERIOR SURFACE COLOR: dark grayish-brown; fire clouds on the rim and body

WALL THICKNESS (RIM, BODY, AND BASE IN MM): rim, $5.2 \mathrm{~mm}$

INTERIOR SURFACE TREATMENT: smoothed

EXTERIOR SURFACE TREATMENT: smoothed

HEIGHT (IN CM): 6.5

ORIFICE DIAMETER (IN CM): 11.0

DIAMETER AT BOTTOM OF RIM OR NECK (IN CM): 10.3

BASE DIAMETER (IN CM) AND SHAPE OF BASE: 7.0; circular and flat

ESTIMATED VOLUME (IN LITERS): 0.43

DECORATION (INCLUDING MOTIF AND ELEMENTS WHEN APPARENT): Plain (Figure 15)

PIGMENT USE AND LOCATION ON VESSEL: none

TYPE AND VARIETY [IF KNOWN]: Unidentified plain ware

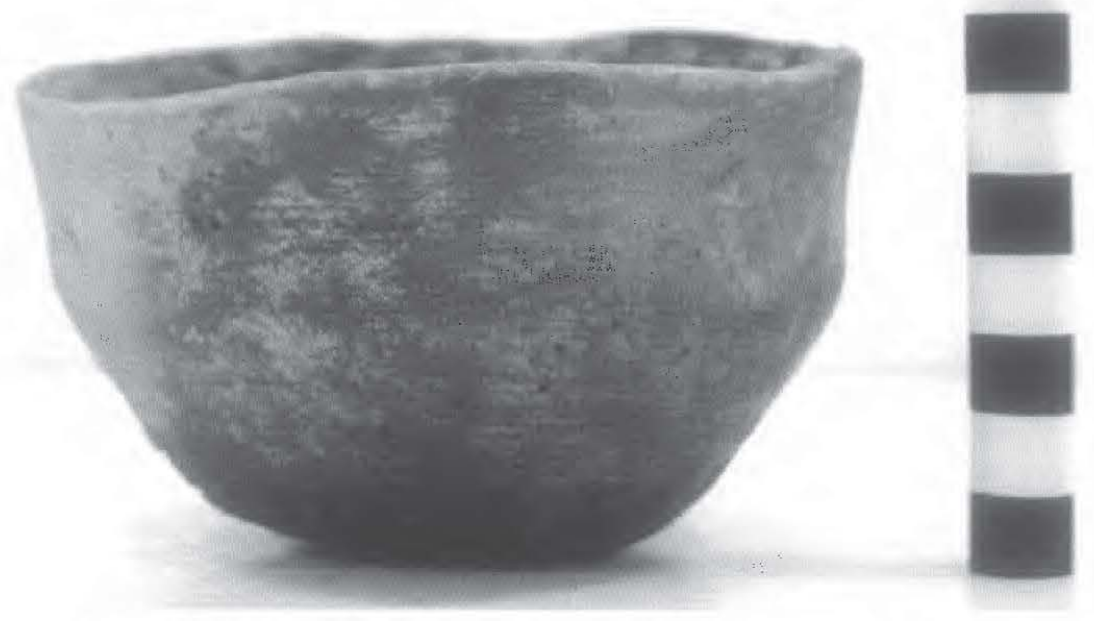

Figure 15. Plain carinated bowl, Burial 4, Vessel 16, at the A. V. Younger site. 
VESSEL NO.: Burial 4, Vessel 18; 2003.08 .206

NON-PLASTICS AND PASTE: grog

VESSEL FORM: Jar with short neck

RIM AND LIP FORM: Everted rim and rounded lip

CORE COLOR: $\mathrm{G}$ (fired in a reducing environment and cooled in the open air)

INTERIOR SURFACE COLOR: dark grayish-brown

EXTERIOR SURFACE COLOR: yellowish-brown; fire clouds on the rim and body

WALL THICKNESS (RIM, BODY, AND BASE IN MM): rim, $6.3 \mathrm{~mm}$

INTERIOR SURFACE TREATMENT: smoothed

EXTERIOR SURFACE TREATMENT: none

HEIGHT (IN CM): 10.8

ORIFICE DIAMETER (IN CM): 10.0

DIAMETER AT BOTTOM OF RIM OR NECK (IN CM): 9.1

BASE DIAMETER (IN CM) AND SHAPE OF BASE: 7.5; circular and flat

ESTIMATED VOLUME (IN LITERS): 0.65

DECORATION (INCLUDING MOTIF AND ELEMENTS WHEN APPARENT): The vessel rim has horizontal brushing marks as well as a single row of triangular tool punctations at the rimbody juncture (Figure 16). The vessel body is divided into six panels by vertical appliqued fillets that extend almost to the vessel base. The panels are filled with brushed-incised marks and lines.

PIGMENT USE AND LOCATION ON VESSEL: none

TYPE AND VARIETY [IF KNOWN]: Pease Brushed-Incised

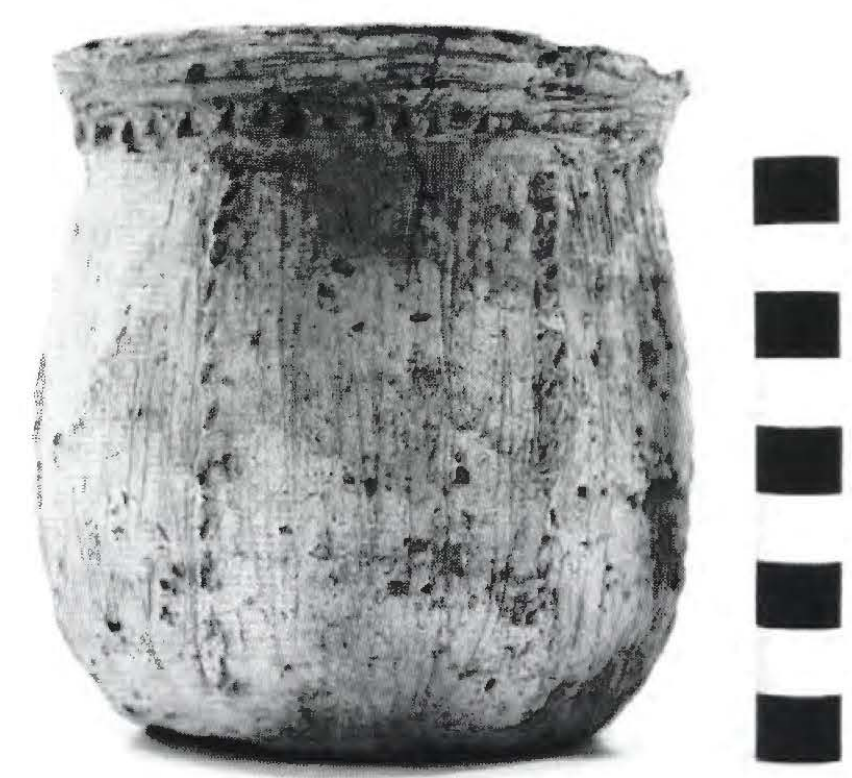

Figure 16. Pease Brushed-Incised jar, Burial 4, Vessel 18, at the A. V. Younger site. 


\section{Ceramic Sherds from Unknown Contexts at the Site}

A total of 290 ceramic sherds were collected by Buddy Calvin Jones from unknown contexts at the A. V. Younger site. The sherd assemblage includes 153 plain body and base sherds and 137 dccorated sherds (Table 1). The plain to decorated sherd ratio is a relatively low 1.12, which is consistent with a I ate Caddo ceramic component in this part of East Texas. The presence of a single Keno Trailed bowl sherd further suggests that this assemblage of sherds may be from a $17^{\text {th }}$ century Caddo occupation.

More than $70 \%$ of the decorated sherds in the A. V. Younger collection are from utility wares. Given the likely Late Caddo age of this ceramic assemblage, it is not surprising that $84 \%$ of the utility ware sherds and $60 \%$ of all the decorated sherds have brushed decorations (see Table 1). Both Harleton Ap pliqued sherds in the collection also have brushing marks surrounding the appliqued elements. Anothcr body sherd simply has a straight appliqued ridge. Two body sherds are from Belcher Ridged, var. Belcher jars (see Girard 2007:15); vessels of this type are typically present in post-A.D. 1500 Belcher phase sites in northwestern Louisiana.

Table 1. Decorated sherds from non-burial contexts at the A. V. Younger site.

\begin{tabular}{|c|c|c|c|}
\hline Decorative element & Rim & Body & $\mathbf{N}$ \\
\hline \multicolumn{4}{|l|}{ Utility Ware } \\
\hline straight appliqued ridged & - & 4 & 4 \\
\hline curvilinear appliqued fillet and parallel brushed surrounding & - & 1 & 1 \\
\hline appliqued fillet chevron and directional brushed & - & 1 & 1 \\
\hline opposed brushed & - & 3 & 3 \\
\hline parallel brushed & - & 78 & 78 \\
\hline parallel brushed-incised & - & 1 & 1 \\
\hline parallel incised lines & - & 6 & 6 \\
\hline curvilinear incised zone filled with tool punctates & - & 1 & 1 \\
\hline vertical ridged & - & 2 & 2 \\
\hline Subtotal, utility wares & - & 97 & 97 \\
\hline \multicolumn{4}{|l|}{ Fine Ware } \\
\hline exterior red-slipped & - & 3 & 3 \\
\hline circle and scroll element* & - & 1 & 1 \\
\hline circle and sunburst element* & - & 1 & 1 \\
\hline curvilinear and rectilinear elements & - & 1 & 1 \\
\hline excised pendant triangle* & - & 1 & 1 \\
\hline hooked arm element** & - & 1 & 1 \\
\hline horizontal line and excised pendant triangle* & - & 1 & 1 \\
\hline int. engraved line & - & 1 & 1 \\
\hline opposed engraved lines & - & 1 & 1 \\
\hline
\end{tabular}


Table 1., cont.

\begin{tabular}{llll}
\hline Decorative element & Rim & Body & N \\
\hline parallel engraved lines & & 6 & 6 \\
parallel engraved lines with excised pendant triangles* & - & 4 & 4 \\
engraved scroll* & - & 1 & 1 \\
engraved scroll and pendant triangles* & - & 1 & 1 \\
single straight engraved line & - & 11 & 11 \\
straight engraved line with spurs & - & 1 & 1 \\
straight engraved line and excised zone & - & 1 & 1 \\
straight and curvilinear engraved lines & - & 1 & 1 \\
single curvilinear engraved line & - & 2 & 2 \\
broad curvilinear trailed lines+ & - & 1 & 1 \\
Subtotal, fine wares & - & 40 & 40 \\
& & & 137 \\
\hline Totals
\end{tabular}

*Ripley Engraved; **Taylor Engraved; +Keno Trailed

The one Keno Trailed body sherd in the collection is from a bowl. 1t has broad curvilinear trailed lines (see Table 1). Other fine wares include 10 sherds from Ripley Engraved vessels, primarily sherds with portions of the pendant triangle motif (Ripley Engraved, var. McKinney, see Perttula et al. 2010), one of the latest (post-A.D. 1600) motifs in Titus phase fine wares. Also found among the fine wares in the A. V. Younger site sherd collection is a Taylor Engraved body sherd with a hooked arm element (see Table 1).

Approximately $90 \%$ of the sherds from the A. V. Younger site are from vessels that are grog-tempered. The remainder are tempered with bone, either as the sole temper or in co-association with grog.

Based on an examination of the sherd core or cross-section, most of the sherds $(67 \%)$ are from vessels that were fired in a reducing environment, but then cooled in the open air, leaving one or both vessel surfaces with a thin oxidized lens visible in the core (Teltser 1993:Figure $2 \mathrm{f}-\mathrm{h}$ ). Another $20 \%$ of the sherds are from vessels that were fired and cooled in a reducing environment (Teltser 1993:Figure 2b), and the remainder of the sherds $(13 \%)$ are from vessels that were fired and cooled in a high oxygen or oxidizing environment (Teltser 1993:Figure 2a).

\section{SUMMARY AND CONCLUSIONS}

In 1964, Buddy Calvin Jones completed investigations at the A. V. Younger site (41MR6) on Arms Creek in the Big Cypress Creek basin and the Lake O' the Pines area. In his work, he gathered a small sherd collection ( $\mathrm{n}=290$ sherds) and found and excavated four Caddo burials on a small terrace landform. Given the placement and spacing of these burials, it is likely that there were more burials at this cemetery location that Jones did not excavate. Based on the collections we recently documented from the site at the Gregg County Historical Museum, as well as notes and drawings prepared by Jones, these four burials were adults that had been placed in an extended supine position in a grave pit, with their heads oriented 
west-northwest and northwest, and a moderate assortment of funerary offerings were placed with each of the deceased individuals. Funerary offerings consisted of 18 ceramic vessels from four burials ( 4.5 vessels per burial), one Bonham arrow point from Burial 1, and one green clay pigment mass with another one of the burials.

The sherd collection from the A. V. Younger site collection gathered by Buddy Calvin Jones is from a late Titus phase (ca. post-A.D. 1600) occupation. It is characterized by high proportions of brushed utility ware jar sherds, as well as Harleton Appliqued and Belcher Ridged, var. Belcher jar sherds. The fine wares are distinctive in that there is a Keno Trailed bowl sherd in the assemblage, along with a Tuylor Engraved body sherd, and a number of late style Ripley Engraved carinated bowl body sherds. The plain and decorated sherds are primarily from grog-tempered vessels that were fired in a reducing or low oxygen environment. The Titus phase ceramic assemblage recognized in the sherd collection is consistent with the temporal and cultural affiliation previously offered by Thurmond (1990).

The 10 vessels we have documented in the A. V. Younger collection are grog-tempered: $10 \%$ have also been tempered with burned bone and other $10 \%$ have both grog and hematite temper inclusions. With our documentation supplemented by notes compiled by Jones, $50 \%$ of the 18 vessels are plain; the plain vessels are small (0.19-0.58 liters in volume). Two vessels are Pease Brushed-lncised jars (one is only 0.65 liters in volume), and three other small vessels (carinated bowls and jars with volumes of 0.25-0.66 liters) have incised-punctated decorations but are not Maydelle Incised vessels. There are two small engraved bottles, including one described as having an engraved rattlesnake motif on it, and two engraved bowls and carinated bowls; one of these had a scalloped lip.

The distinctive assortment of vessels from the four excavated burials at the A. V. Younger site do not appear to be associated with the previously recogmized Titus phase component. Rathcr, the burials appear to be from an older component, one that likely dates to the Middle Caddo period (ca. A.D. 1200-1425). It is not known if there is a Middle Caddo domestic habitation area at the A. V. Younger site. We offer this conclusion about the age of the four burials from the A. V. Younger cemetery lor the following reasons: (a) the absence of Titus phase decorated ceramic vessels, including Ripley Engraved as well as brushed utility wares; (b) the high proportion of plain vessels in the assemblage, which is not characteristic of most Titus phase burial assemblages in the Big Cypress Creek basin; (c) the occurrence of Pease Brushed-Incised vessels, which commonly were made in used in Middle Caddo period types, just as they were in later Titus phase contexts; (d) the engraved rattlesnake bottle and the engraved scalloped bowl, which are particularly characteristic of Middle Caddo ceramic assemblages in this part of East Texas (Hart and Perttula 2010; Walters 2006, 2010); and (e) the fact that onc Bonham arrow point was among the funerary offerings in one burial. Bonham arrow points are characteristic burial funerary offerings in Middle Caddo sites in the region (cf. Perttula et al. 2007; Walters and Haskins 1998).

\section{ACKNOWLEDGMENTS}

We wish to thank the Gregg County Historical Museum for the opportunity to document these collections from the A. V. Younger site. Patti Haskins was especially helpful in facilitating this study. Lancc Trask prepared the figures in this article and Bo Nelson took the photographic images.

\section{REFERENCES CITED}

Girard, J.S.

2007 Byram Ferry (16BO17): A Middle to Late Caddo Period Mound Site in the Red River Floodplain, Northwest Iouisiana. Caddo Archeology Journal 16:9-25. 
Hart, J. P. and T. K. Perttula

2010 The Washington Square Mound Site and a Southeastern Ceremonial Complex Stylc Zone among the Caddo of Northeastern Texas. Midcontinental Journal of Archaeology 35(2):199-228.

Miller, E. O., E. H. Moorman, and E. B. Jelks

1951 Archeological Survey of Ferrell's Bridge Reservoir: Harrison, Marion, Upshur, Cass, Morris, Titus and Camp Counties, Texas. Report submitted to the U.S. Army Corps of Engineers by the National Park Service and the Smithsonian Institution River Basin Surveys. Austin.

Perttula, T. K., M. Walters, and B. Nelson

2010 Caddo Pottery Vessels and Pipes from Sites in the Big Cypress, Sulphur, Neches-Angelina, and Middle Sabine River Basins in the Turner and Johns Collections, Camp, Cass, Cherokee, Harrison, Morris, Titus, and Upshur Counties, Texas and Sabine Parish, Louisiana. Special Publication No. 10. Friends of Northeast Texas Archaeology, Pittsburg and Austin.

Perttula, T. K., M. Walters, R. Cast, B. Gonzalez, and B. Nelson

2007 Documentation of Funerary Offerings from a Prehistoric Caddo Burial at Site 4IWD244, Wood County, Texas. Caddo Nation of Oklahoma and Archeological \& Environmental Consultants, LLC, Binger and Austin.

Suhm, D. A. and E. B. Jelks (editors)

1962 Handbook of Texas Archeology: Type Descriptions. Special Publication No. 1, Texas Archeological Society, and Bulletin No. 4, Texas Memorial Museum, Austin.

Teltser, P. A.

1993 An Analytic Strategy for Studying Assemblage-Scale Ceramic Variation: A Case Study from Southeast Missouri. American Antiquity 58(3):530-543.

Thurmond, J. P.

1990 Archeology of the Cypress Creek Drainage Basin, Northeastern Texas and Northwestern Louisiana. Studies in Archeology 5. Texas Archeological Research Laboratory, The University of Texas at Austin.

Walters, $M$.

2006 The Lake Clear (41SM243) Site and Crotalus horridus atricaudatus. Caddoan Archeology Journal 15:5-41.

Walters, M., with contributions by T. Middlebrook and T. K. Perttula

2010 Redwine or Pie-Crust Mode Forms in East Texas Caddo Ceramics and comparisons with SproketRims of Southwest Arkansas. Caddo Archeology Journal 20:77-128.

Walters, M. and P. Haskins

1998 Archaeological Investigations at the Redwine Site (41SM193), Smith County, Texas. Journal of Northeast Texas Archaeology 11:1-38. 